\title{
NOTES ON REPTILES AND BATRACHIANS COLLECTED IN FLORIDA IN 1892 AND 1893.
}

\author{
By Einar Leennberg, Ph. D., \\ University of Upsala, Sweden.
}

THE following notes are based upon a collection made during a sojourn in Florida from September, 1892, to July, 1893, during which time I was engaged in general zoological collecting and research. The list contains the greater majority of the species recorded from that part of the United States, besides a number of additions to the herpetological fauna of Florida. The distribution of other species within the peninsula has been extended, or better defined. The biographical notes may not contain any strikingly new facts, but as such observations are not very commonly recorded, and as mine are based on personal experience they may possess some value as corroborative evidence.

I wish, finally, to express my grateful acknowledgment for kind assistance received from the authorities of the U. S. National Museum.

\section{REPTILIA.}

\section{TESTUDINES.}

\section{PLATYPELTIS FEROX ( Schneider).}

The soft-shelled turtle abounds in all lakes and ponds in south Florida. It is caught with nets and seine and readily takes the hook. It is very savage and bites ferociously.

\section{DERMOCHELYS CORIACEA (L i $\mathrm{n} n$ æ $\mathrm{u} \mathrm{s}$ ).}

This turtle seems to be known to some of the people living at Key West, but it is very rare. I have only seen one specimen in Florida, which had been caught near St. Augustine.

\section{CHELONIA MYDAS ( $\mathrm{L}$ i $\mathrm{n} \mathrm{n} \circledast \mathrm{u} \mathrm{s}$ ).}

Green turtles are still common along the coast of south Florida, but the time of extermination will soon come, as they are caught in great 
numbers with nets, harpoons, pegs, etc., in the water, as well as on the beach when laying their eggs, the eggs being secured at the same time. The meat is sold at 10 cents a pound, and a good many are shipped North alive from the Key West market. The largest specimens reach a weight of 800 pounds.

\section{ERETHMOCHELYS IMBRICATA ( $\mathrm{L}$ i $\mathrm{n} \mathrm{n} \approx \mathrm{u} \mathbf{s}$ ).}

The hawksbill turtle is eaught at Key West, where I have seen some. It is not common, and very high in price on account of the shell. It is said to reach a weight of 150 to 200 pounds, but specimens of that size are very scarce.

THALASSOCHELYS CARETTA ( $L$ i $n \mathrm{n}$ æ $\mathrm{u} s$ ).

The loggerhead turtle is common all round the coast of south Florida, especially among the Keys. It is used for food in some places, for instance at Key West, although not so palatable as the green turtle, and the eggs are eaten whenever they can be found. The eggs are laid in May and June. During the latter month I found them on the Coronado beach at New Smyrna. Although the animals themselves are not always caught, the custom of taking their eggs is as destructive in the long run, and they are going to be exterminated on the coast of Florida sooner or later. They do not grow larger than 300 pounds.

DEIROCHELYS RETICULARIA ( $L$ a t $\mathrm{r}$ e i $11 \mathrm{l}$ ).

This species is not common so far as I know. I have only seen 2 specimens in south Florida, both of which were caught at Clarcona, Orange County, by C. C. Allen, who generously presented one of them to me.

PSEUDEMYS RUBRIVENTRIS (L e c o n t e).

The red-bellied terrapin, or cooter, is not so common in south Florida as Pseudemys concinna, but I have seen it in several localities, viz, in the St. Johns River; at Clay Springs, Orange County; Silver Springs, Marion County, etc. It is to be found not only in the rivers, but I have eaught it with the seine in small lakes in the neighborhood of Apopka, and have likewise received from Mr. C. C. Allen a specimen from Clarcona, Orange County. The plastron is sometimes uniform red; sometimes marbled with black.

PSEUDEMYS CONCINNA (L e c o n te).

This is the common cooter of Florida, in which country it is abundant in all lakes and rivers. They are very often seen in great numbers basking on old logs in the water, even in the middle of the winter. They feed on vegetable matter. The meat is white and very palatable. 
MALACLEMYS CENTRATA (Latreille).

The valued diamond-back terrapin is caught in the salt marshes along the east coast. I obtained several specimens at Hillsboro River, outside New Smyrna, Volusia County.

\section{TERRAPENE CAROLINA (L inn $\mathrm{u} \mathrm{s}$ ).}

The box-turtle is not very common in the southern part of Florida. I saw only two specimens in Orange County, viz, at A popka and Clarcona. It is said to be more abundant around St. Augustine.

\section{GOPHERUS POLYPHEMUS (D a u d in ).}

The "gopher" is common in the dry woods of south Florida. It is diurnal in its habits and is often seen walking about feeding between $11 \mathrm{a} . \mathrm{m}$. and $3 \mathrm{p}$. m. When disturbed it retracts its head and feet with a hissing sound, like that of a snake, and sometimes tries to bite. The people do not use these animals for food, but sometimes chop them up and give them to the chickens. It is said that the holes are dug down to the ground water. A good many animals, as rabbits, snakes, frogs, etc., seek a refuge in the gopher holes, which are of particular protection to them when the grass in the woods is burnt off.

Lately there was discovered a quite interesting fauna of insects, partly blind, which live in these holes. *

\section{KINOSTERNON BAURII (Ga rman).}

At three different places in Orange County I collected this little turtle, which is new for the peninsula, but has been found at Key West and in Cuba before. I saw it first in Fern Creek, near Orlando, later at Apopka and Oviedo, in the same county. It is easily distinguished from $K$. pensilvanicum by the different development of the plastron and the color, etc. On the head there are always two pale yellow streaks, one from the tip of the nose backwards through the upper margin of the eye, the other one from the inferior margin of the eye and backwards. Below there are two broader bands of the same color on the inferior surface of the mandibula. The carapace shows three pale longitudinal bands. The shell is not smooth, but worn and eroded by parasitic algæ.

One of the specimens collected in Orange County is now in the U.S. National Museum (No. 21326).

\section{KINOSTERNON PENSILVANICUM (G melin).}

This species is quite common in some localities in the small lakes and creeks, etc.; for instance, in Fern Creek, near Orlando, Orange County. It is sometimes called the mud turtle.

${ }^{*}$ Henry Hubbard, Science, xxiI, August 4, 1893, pp. 57-58. 
AROMOCHELYS ODORATA ( D a u d in).

The musk turtle is common in pouds and creeks in south Florida. In Fern Creek, for instance, it is abundant, and I have also found it in several other places in Orange County. One of my specimens from the above mentioned creek is very interesting on account of several anomalies of the plates of the plastron. The gular plate is divided by a very distinct suture and there is a pair of plates between the femoral and anal plates representing the anterior portion of the anals. The plastron is thus covered by 14 plates. Otherwise this specimen is typical in color and shape.

\section{CHELYDRA SERPENTINA ( L innæus).}

The alligator turtle is not very common in south Florida. I know of specimens from St. John's River, Lake Apopka, and the neighborhood of Oviedo, Orange County. As the head is very large, some ignorant people call it the "loggerhead," which name properly belongs to Chelonia caretta.

\section{SAURI.}

ANOLIS PRINCIPALIS ( $\mathrm{L}$ in $\mathbf{n} æ u \mathrm{~s}$ ).

The "chameleon" is common all over south Florida. It often enters the houses and frequently you can see this charming little animal climbing on the curtains in your room. It is interesting to see them run about in the sunshine and suddenly change color from brown to the most resplendent emerald green and to observe the males how after some nodding movement with the head they inflate the ruby colored gular sac. They are very fond of running on the thistles, where they readily find their way between the spines and prickles, being at the same time well protected by them against their enemies. The shape of the head varies considerably, but I am not able to draw any line between the short-snouted and the long-snouted ones, as there are all degrees of intermediates.

\section{SCELOPORUS UNDULATUS (D a u $\mathrm{d}$ in).}

These lizards are very common in south Florida, in the pine woods and among the oaks in dry places, on old fences and houses, ete. When running on old burned stumps and logs in the pine woods, which used to be burned every winter to get better grass for the cattle, they are able to turn perfectly black. On light ground, for instance on oak bark, they resume their gray color with the brown undulations on the back, thus showing themselves possessed of a great faculty of adapting their color to that of the surroundings. They are sometimes called "alligator lizards," on account of the roughness of their scales.

\section{OPHISAURUS VENTRALIS (L innæus).}

The "glass snake" has received its name because the tail is so very brittle. Ignorant people believe that the broken pieces are able to join 
together again, and therefore call it "joint snake." This harmless lizard is also considered by them to be a very "poisonous snake." Ophisaurus is not scarce in south Florida, and I have found it in all kinds of places, in the dry pine woods, in hammocks, and under old logs at the border of lakes. It is a burrowing animal, and is therefore sometimes plowed up.

\section{CNEMIDOPHORUS SEXLINEATUS ( $\mathrm{L}$ i $\mathrm{n} \mathrm{n} æ \mathrm{u} \mathrm{s}$ ).}

This swift is extremely abundant on Key West, and the largest and nicest specimens in my collection were caught there. Although so abundant, it is hard to collect, as it is so very quick and active, running through the shrubs and disappearing "quick as a flash of lightning." In other parts of south Florida it is very common, too, in dry places in the pine lands, and on warm and sunny days may be seen all over the country in such places as, for instance, around Orlando and Oakland, Orange County, etc., but it does not seem to do as well anywhere as at Key West on the warm lime rocks and in the dense scrub.

\section{EUMECES FASCIATUS (L in $\mathrm{n} \circledast \mathrm{us}$ ).}

This lizard is rather common in south Florida under rotten logs and stumps and similiar places. It is not confined to the hammocks, isut is also found in the pine woods, in suitable localities, and I have seen a large specimen on the island south of Hog Island outside of Clear Water Harbor, Hillboro County. Strange to say, it is called "scorpion," "blue tail scorpion" or "big scorpion" and regarded as "awfully poisonous." The bright blue tail is very brittle and breaks always if one tries to catch the animal by that member.

\section{LEIOLOPISMA LATERALE (S A y).}

This lizard is one of the smallest in south Florida, where it is abundant in hammocks under old leaves, etc., or on the shores of lakes under logs and stumps. The localities frequented by this skink are always more or less moist; the tail breaks off easily and is as easily reproduced.

RHINEURA FLORIDANA (B a i r d).

The "blind worm" or "blind snake," as it is called, is not scarce in sandy places in Orange county. It is often found by people digging or grubbing in the gardens or plowing in the orange groves.

\section{SERPENTES.}

CEMOPHORA COCCINEA (Blumenbach).

The amount of individual variation displayed by the present species seems to be considerably greater than one would suspect from a perusal of the literature. Baird and Girard* indicate a variation in the

* Catalogue of North American Reptiles, I, Serpents, p. 118.

Proc. N. M. $94-21$ 
nasal plate, a point brought out fuller by Garman,* who describes it as "entire, sometimes grooved or half divided, occasionally divided." The former authors also indicate a certain variability in the size of the supraocular. Finally, Jan has described a specimen as a separate subspecies which had the loreal extending to the orbit beneath the preocular. $t$ My specimen, which is from a hammock near Lake Charm, Orange County, the only one obtained by me, has the nasal completely divided. In addition it has 7 upper labials, third and fourth entering the eye, the center of the eye above the fourth, and 9 lower labials, instead of normally 6 supralabials and 8 infralabials. It will be noticed, however, that Jan $\ddagger$ figures a specimen from New Orleans with 7 supralabials like mine, and Dr. Stejneger informs me that the U.S. National Museum possesses several specimens with the same number, for instance, No. 10741, from Clear Water, Fla., and No. 6298, from Fort Jesup, La. He also mentions 3 other interesting specimens, viz: No. 5221, from northern Alabama, which on one side has a rather large subpreocular wedged in between the second and third supra labials; No. 2387, from Anderson County, S. C., in which the rostral extends so far backward as to entirely separate the internasals; and No. 14828, from Georgiana, Fla., with the loreal and supraocular so small as to allow the prefrontals to separate them and enter the eye between them.

The size of the supraocular is not particularly small in my specimen; the number of temporals are $1+2+2$; the number of gastrosteges about 180. The number of the latter is given by Garman $\S$ as varying between 157 and 174 . In my specimen there are 17 pairs of black rings on the body and 6 on the tail, nearly the normal number. The specimen described by Jan and referred to above has an unusually large number of black rings, but Dr. Stejneger informs me that the U.S. National Museum specimen No. 6298 mentioned above has quite as many, but with the loreal normally related.

My specimen was obtained by digging in the ground. The burrowing habits of this species are evidently the cause of its comparative rarity.

\section{FARANCIA ABACURA ( $\mathrm{H}$ o $\mathrm{l}$ b r o o $\mathrm{k}$ ).}

I obtained several small specimens in Lake Eola, at Lake Brantleg, and at other places in Orange County. Two larger ones were dug up in a "bay-head" at Oviedo, in the same county, in spite of the fact that the people there did not know it and had no name for it.

The U. S. National Museum has received a specimen from Arlington, Fla., No. 9583, collected in 1878 by Francis C. Goode.

\section{ABASTOR ERYTHROGRAMMUS (D a u d i u ).}

I have not found this species in south Florida, but have seen a specimen caught not far from St. Augustine.

\footnotetext{
${ }^{*}$ Garman, S., Mem. Mus. Comp. Zool. Cambr., II, p. 78 (1883).

† Iconographie des Ophidiens, livr. 11, pl. v, fig. 3.

$\ddagger$ Loc. cit., fig. 1.

$\S$ Loc. cit.
} 
CONTIA PYGEA (C o p e).

I have but rarely found this little snake out of the water, and in such cases only under some log or board near the water's edge. It is common around the borders of the small lakes in Orange County, where I have seen and caught specimens in Lake Eola, Orlando, in and around some small lakes near Clarcona, Toronto, Apopka, and other places.

The number of supralabials is variable. In most cases there are 8, but I have two specimens with only 7 , and one with only 6 on one side. In these cases of reduction the posterior ones have become fused, as show $\mathrm{n}$ by their size and the frequent presence of an incomplete section. The rows of scales are always 17 on all my specimens. The color of the upper surface is sometimes a little lighter on the sides, showing conspicuously on the three lowermost rows, at least, a narrow light stripe along the middle of each series. The belly is salmon-red without any spots, but in some specimens there is on the side of each gastrostege a short stripe extending to about a fourth or a fifth of the belly, forming the beginning of cross-bars.

STILOSOMA EXTENUATUM, B r o w n .

This rare and recently described snake* was hitherto known from one specimen only, the type. The three specimens obtained by me

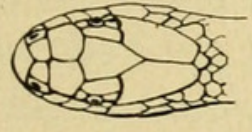

1

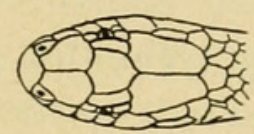

2

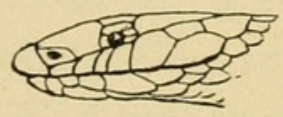

3

Stilosoma extenuatum (twice natural size).

Fig. 1. Head from above (No. 21327, U. S. N. M.). Fig. 2. Head from above. Coll. Zool. Mus. Univers. Cpsala, Sweden. Fig. 3. Head from the side; same specimen as fig. 2.

in Orange County, viz, one at Lake Charm, near Oviedo, the others at Oakland, deviate in their scutellation of the head to an extraordinary degree from the type, which appears greatly abnormal, so much so in fact that the generic determination became one of great uncertainty. One of the specimens has been presented to the U. S. National Museum (No. 21327), and submitted to the curator of reptiles, Dr. L. Stejneger, who is responsible for the identification as well as for the following remarks:

The type specimen of Stilosoma extenuatum is described as possessing no separate prefrontals (these being fused with the internasals), no loreal, and no preoculars. The large internasals join the supralabials and enter the eye, and the parietals join the supralabials behind the postoculars, excluding the temporals from the latter.

The three additional specimens seem to prove that the only normal and stable characters among the above are the absence of the loreal and the joining of the parietals and supralabials. The absence of the preocular is only found in the type, while the fusion of the internasals with the prefrontals is found in the type and in one of the Orange County specimens as well, but not in the other two, in which they are normally separated.

${ }^{*}$ Brown, A. E., Proc. Phila. Acad., 1890, p. 199. 
The absence of the preocular in the type of Stilosoma extenuatum, or rather its fusion with the prefrontals, at first led to suggestion of even more than specific difference, but a reflection upon the fact that the difference between the additional specimens themselves is fully as large as between them and type, coupled with the otherwise complete agreement with Brown's original description, soon led to the abandonment of such an idea.

The following additional remarks are derived from the specimen in the U. S. National Museum:

Hypapophyses absent in the posterior dorsal vertebræ; maxillary teeth eleven, all smooth, in a continuous series, the anterior and posterior ones siightly shorter than the others; pupil round; two pairs of well-developed, long chin-shields in contact on median line; preocular rather small, square, in contact with supraocular, prefrontal, second and third supralabials; six supralabials; temporals $1+2$, the anterior one separated from postoculars by parietals which are very 1ong; gastrosteges, 260; anal, 1 ; urosteges $\frac{40}{40}+1$. Total length, $330 \mathrm{~mm}$.; tail, $23 \mathrm{~mm}$.

Mr. Brown compares the coloration of the present species with that of Rhinocheilus lecontii, while Cope* states that it "has the coloration of the type of Hypsiglena or Sibon." None of these comparisons seem particularly happy, while on the other hand the similarity of Stilosoma extenuatum, so far as color and pattern, both above and below, is concerned, to Lampropeltis calligaster is very striking indeed. Even the head markings are almost identical.

On the whole the totality of the characters seems to place this genus among the coronelline snakes rather than with the calamarines, in spite of the marked tendency to a reduction of the number of head-shields by fusion, and it may be well in this connection to call attention to the unusually great number of gastrosteges, viz, 235-260.

\section{LAMPROPELTIS GETULUS ( $L$ i $n \mathbf{n} æ u \mathrm{~s}$ ).}

Rather common in south Florida, where it is sometimes known under the name of "king snake," and is then said to kill and devour the rattlesnake. Sometimes it is called "rattlesnake pilot," and is then regarded as the guide of that snake!

My specimens have the normal number of 21 rows of scales, while Cope has examined some Florida specimens with 23 rows. The coloration varies greatly. Sometimes the yellow centers of the scales result in more or less well-defined crossbands on the back and the yellow color on the interspaces is less conspicuous. Sometimes there are no distinct crossbands and then the snake looks brown or yellow, depending upon the development of the yellow centers of scales, which sometimes occupy nearly their entire surface. The crossbands, when present, often bifurcate on the sides, embracing darker areas. In this variety the crossbands and forks are narrow, becoming broader inferiorly, often as broad as the dark areas.

Most specimens of mine from Florida have yellow centers on the scales, more or less, even if they are crossbanded. A more typical L. getulus black with whitish crossbands, was caught at Savannah, Ga., by Capt. C. Eckman, and presented to the Upsala Museum. Lampropeltis getulus is of a rather gentle disposition. When caught they never

* Proc. U. S. Nat. Mus., xiv, 1891, p. 595 (1892). 
tried to bite, only one opened its mouth, but they wind themselves round one's arm, showing great muscular strength. When they get alarmed they often rattle with the tip of the tail, trying to scare the enemy.

I have seen eggs laid by an L.getulus in captivity. They were rather large, whitish and with soft skin.

All my specimens were taken on dry land.

OSCEOLA ELAPSOIDEA ( $\mathrm{H}$ olbrook).

I have one specimen of this beautiful snake from Key West, and another from the neighborhood of Toronto, Orange County. In both there is on one side a small rudimentary loreal, but on the other side the prefrontal extends to the upper labials. One who has seen both Cemophora and Osceola can not well confound them afterwards. The shape of the head is entirely different. Osceola deserves well the cognomen "elapsoidea." The form of the head is very similar to that of an Elaps, and so are the colors, black, red, and yellow, although arranged differently. On the specimen from Toronto the seventeenth* pair of black rings is situated over the anus and there are five pairs on the tail, the last not complete. On the specimen from Key West the sixteenth* pair is situated over the anus. On the latter specimen the black rings are broader and cover 4-5 scales, aud in the middle of the back they have a teudency to extend into the red spaces, so that, for instance, the posterior one of the twelfth, thirteenth, and fourteenth pairs extend through the red, meeting the anterior band of the thirteenth, fourteenth, and fifteenth pair respectively. It is remarkable that the yellow iings, although narrower, are never intruded upon. The fact that in Elaps fulvius the red, but never the yellow, is very often dotted with black, forms an interesting parallel.

DIADOPHIS PUNCTATUS (Linnæus).

Having obtained this snake only once, not far from Apopka, Orange County, in April, 1893, I must regard it as rather uncommon in that part of the State.

My specimen has two anterior and three posterior oculars instead of $2-2$, but is otherwise typical as to scutellation and color.

There are nine specimens of this species in the U. S. National Museum from Florida, included under the following eatalogue numbers: No. 10585 from Clear Water, collected by S. T. Walker; and Nos. 11984, 13667, 13702, from Georgiana, by Wm. Wittfield.

OPHEODRYS ASTIVUS (Linnæus).

This beautiful and gentle little snake is to be found all over south Florida down to Key West in "hammocks" and "scrubs." It is often 
seen in orange trees. I have never observed it on the ground. It never tries to defend itself in any way.

\section{BASCANION CONSTRICTOR ( $\mathrm{L}$ i in $\mathrm{n}$ : $\mathrm{u} \mathrm{s}$ ).}

The black snake is the commonest snake in South Florida and may be seen everywhere-in the dry pine woods, in the small prairies, at the borders of the lakes, on the ground, or climbing trees, or escaping down into the "gopher" holes.

At Acadia, De Soto County, I captured a small black snake which was crawling on the upper leaves of a palmetto, and as it presents some peculiarities it may be well to describe it in detail. It was very slender, being $600 \mathrm{~mm}$. in total length, with a tail measuring $180 \mathrm{~mm}$; body compressed and head much broader than neck. The color of the upper surface is as black as in any full grown B. constrictor; the belly is likewise black, but with a narrow median stripe of small, whitish, cloudy spots; chin, throat, and upper labials whitish; this color extends back over the first 17 gastrosteges, the posterior ones of which are spotted with black. When killed the belly was speckled all over with round orange red or rusty spots of a diameter of 1 to $2 \mathrm{~mm}$., but these have disappeared in alcohol. Tip of tail underneath, yellowish. Scale rows, 17. Eight supralabials instead of 7 as usual in B. constrictor. Three postoculars, a peculiarity shared in by another full-grown specimen in my collection. On the whole there seems to be a great variation in the number and relation of these scales and in the temporals, of which there are 6 ou one side and 7 on the other in my specimen.

According to Dr. Stejneger, to whom I have submitted the specimen for examination, it is a young one in transition to the adult coloration, which it has not yet quite fully acquired.

\section{BASCANION FLAGELLUM (Sha w).}

This species is not so abundant as the foregoing one, and is mostly found in dry pine woods in which the soil is rich enough to allow oak trees to grow. It is common around Oakland, Orange County.

It is known as the "coach whip" and sometimes the larger ones are called "chicken snakes," like several other of the larger colubrine snakes. Although a bold fighter and sometimes even found to be the attacking party, it is, of course, perfectly harmless, though some of the ignorant natives fear it greatly, believing that with "a blow of its tail it can break the arm of the largest man."

\section{CALLOPELTIS GUTTATUS ( L i n $\mathrm{n} æ \mathrm{us}$.)}

I have specimens of this snake from Ozona Hillsboro County, Orlando, Oakland, Apopka, Oviedo and other places in Orange County; from the dense scrub at Coronado beach, New Smyrna, in Volusia County, and from Key West. It is known by different names in different places; for instance, "chicken snake" at New Smyrna and Key 
West; "house king-snake" at Oakland, etc. It rattles its tail when offended, and one of my specimens tried to defend itself by biting. Like the following species, it often enters into the houses to hunt rats. The color is different in different specimens. I have not obtained any typical C.g. sellatus (Cope), though on the specimen from Key West the head bands are more obscure and the lateral spots not well defined, some of them-the posterior ones-being rather faint and disappearing on the tail; many of the dorsal spots are open on the sides, having only anterior and posterior dark borders; only the anterior part of the lower surface is regularly tessellated with black spots; further back there is only a trace left of each black square, and the abdomen thus becomes finely mottled with blackish scales not keeled.

Another specimen from Orlando shows variations in the direction of Callopeltis rosaceus (Cope). The belly is checkered and the head is banded in the normal way, but on the back two dark brown stripes extend all the way through the dorsal spots. On the anterior part of the body the lateral black borders of the dorsal spots, as well as the upper black borders of the lateral spots, extend longitudinally from one spot to another, in this way forming longitudinal stripes. A little further back this double black stripe is interrupted, but a less sharply defined brown stripe connects the lateral black border of an anterior dorsal spot with the next behind. Still further back even that brown stripe disappears, and the spots have the same appearance as in a common C.guttatus. Even in a young specimen from Ozona, Hillsboro County, there is a tendency to a longitudinal connection of the spots on the sides of the anterior part of the body, but there are no longitudinal dorsal stripes to be seen. The above-mentioned variations are very interesting, and in the future, I suppose, there will be found more connecting links between the various forms clustering around $C$. guttatus.*

\section{CALLOPELTIS QUADRIVITTATUS (Holb rook).}

I have obtained specimens of this form from different places in Orange County. It is often found in trees, being a very good climber. It enters very often the houses to hunt rats. Caged birds frequently become its prey on such excursions. Why the larger specimens are called "chicken snakes" is easy to understand.

The young ones are spotted, and sometimes these spots remain conspicuous in older specimens, too. I once saw quite a large specimen shot in a packing house, where it had been a regular guest for some time. This snake measured nearly two meters and had large yellow saddle blotches on its back. It was too much damaged to be preserved.

\section{SPILOTES CORAIS COUPERII (Holb rook).}

This snake, which is generally called "gopher snake" in south Florida, is not very common. I have obtained only one specimen from

\footnotetext{
${ }^{*}$ From Savannah, Ga., I have a specimen of Callopeltis spiloides but I have not seen this species in Florida.
} 
the neighborhood of Orlando, Orange County. It had 7 superior labials on the right side and 8 on the left, showing plainly that this character is not constant.

The red on the throat is more or less developed in different specimens. The gopher snake is one of the largest snakes in Florida, and one often hears of specimens of extraordinary size. I have seen some stuffed specimens in St. Augustine which were about 10 feet in length.

I do not know much about its habits, but it seems to prefer high and dry land. It is said to be rather slow moving.

\section{PITUOPHIS MELANOLEUCUS (D a u di in).}

The common form of this snake in South Florida has large, reddish saddle blotches on the back, becoming anteriorly more and more obsolete and finally showing only a slight mottling on the yellowish gray ground color. I have a smaller specimen on which the dorsal spots are blackish or dark brown, corresponding with Holbrook's figure.* The number of spots on the body is about 28 , but the anterior ones are dissolved into smaller ones and difficult to distinguish. Two faint bands can be seen from the eye to the seventh supra-labial and from eye to eye in a curved line across the posterior part of the prefrontals. Supralabials, 8; ocular, 1-4 on the left side, 1-3 on the right.

From its loud hissing it is called "bull snake," and "pine snake" from its living in the pine woods. All the specimens observed by me are from dry, sandy pine woods in Orange County.

The skin of a very large specimen measured, without head and tail, 170 c. $\mathrm{m}$. and must have been at least $2 \mathrm{~m}$. This skin was given to me as the skin of a "chicken snake."

A very large specimen when eaught hissed loudly and opened its mouth, but did not bite. It rattled its tail at the same time.

\section{HETERODON PLATYRHINOS, L a tre ill e}

The spreading adder is very common in South Florida. I have seen it most frequently in dry places in the pine woods, "highland hammocks," orange groves, etc. In the last named it is often plowed up.

Although the spreading adder is not a poisonous snake, it is very much dreaded as such. If it should bite it would probably inflict a considerable wound with the large posterior teeth. I have heard of two or three cases in which spreading adders are said to have bitten. These may, nevertheless, be regarded as rare exceptions. In one of these cases it was said that the hand of the bitten man swelled up considerably. He believed that the snake was poisonous, and so did the doctor, therefore the patient was ordered to drink so much whisky that he was nearly killed, and the doctor applied digitalis and other strong poisons. The man was a strong fellow and survived the treatment.

${ }^{*}$ Holbrook, J. E., North American Herpetology, 2 ed., iv, pl. i. 
The bites of harmless snakes may become dangerous from several reasons: (1) Common blood poisoning that can happen with any wound; (2) poisoning with the poison from the skin of toads, in cases of bite by species feeding on these animals, as I often have observed that it is possible for some of the secretions from the poison glands in the skin of the toad to remain in the mouth of the snake among the teeth, especially the larger posterior maxillary teeth which inflict the wound; (3) fear that the snake is poisonous and consequent self-suggestion.

A large specimen of the black spreading adder Heterodon platyrhinos niger (Daudin) that I received in Orlando, Orange County, from Mr. L. Robinson, did not act quite like the gray specimens of the same species. It flattened the head and the neck, but not the body, and made itself very thick. The gray ones used to keep the head down to the ground during their contortions, but this one raised the head, moved it forward and backward, hissing very loudly but without biting. The hissing sound was produced at the time of expiration; at the time of inspiration there was a weak snoring sound.

\section{THAMNOPHIS SIRTALIS ( $\mathrm{L}$ i $\mathrm{n} \mathbf{n} æ \mathbf{u} \mathbf{s}$ ).}

This beautiful snake called "Grass snake," or sometimes "Garter snake," is quite common in wet places in south Florida, where I have obtained several specimens from different places in Hillsboro, Orange, and Osceola counties. They vary in color, some being more brown, others more green or bluish green; in some the spots are more distinct, in others the stripes, but in all my grown specimens stripes as well as spots are conspicuous, and all belong to the typical form. A young specimen caught at Lake Eola, Orange County, has no stripes, but two rows of square spots on each side, and is thus similar to Thamnophis sirtalis ordinata (Linnæus).*

The grass snake is ill-tempered and even a small one will bite ferociously.

A big female of this species, kept in captivity by a taxidermist, one night gave birth to about 40 young ones that were scattered all over the floor when the owner entered the store in the morning.

THAMNOPHIS SACKENII, Kennicott.

This species is said to be characteristic for Florida. I obtained 3 specimens at Oviedo, Orlando, and Apopka, in Orange County. All were canght in the grass in wet places. A specimen in the Upsala Museum, collected by Capt. C. Eckman, at Savannah, Ga., has 8 labials on one side, but 7 on the other, and another specimen from the same place has only 7 on each side. They are olive green but approach Th. saurita so much that I hardly think Th. sackenii can be maintained except as a southern variety.

\footnotetext{
*Tropidonotus ordinatus, НоцвRоок, North American Herpetology, 2 ed., IV, pl. xii.
} 


\section{LIODYTES ALLENII (Gั a rman).}

In a cypress swamp a few miles south of Kissimmee, Osceola County, I killed a big moceasin (Agkistrodon piscivorus), and found in its œsophagus a smaller snake which it had probably just swallowed. It was well preserved, except in one place on the middle of the body, where it had probably been bitten by its devourer. This is the only specimen of Liodytes allenii that I have happened to find, and I suppose it is scarce. It corresponds with the description given by Cope, viz:* Color dark brown with two brownish-yellow stripes on each side; below straw color; to which I can add a median row of blackish-brown spots, one on each gastrostege and a median zigzag stripe of the same color underneath the tail between the scutella. The single internasal and the five rows of keeled scales on the tail are very characteristic. The fact that the scales on the tail are keeled, as well as the circumstances under which I found it, indicate that it is a water animal.

Oculars 2-3 in my specimen, but in another in the Upsala Museum, $\uparrow$ eaught by forest inspector Westerlund, probably at Oakland, Orange County, the oculars are 1-3 (now No. 21388 U. S. N. M.).

\section{NATRIX COMPRESSICAUDA (K e n n i cott).}

Wading through a mangrove swamp at Key West I met, one day, with a blackish looking snake that eame rapidly swimming through the water. I caught it and have classified it as belonging to this species, but the color is different from the "subspecies" Cope gives. $\ddagger$

I will describe it, and if a name should be needed "obscura" is a good and suitable one. Scales in twenty-one rows. The color of the back is dark blackish gray, "soot color." On this ground the three series of spots can scarcely be distinguished, except on the anterior part of the body, where they form transverse bands; the head is too dark to show any postocular bands; upper and lower labials as well as mentals, with yellowish spots; the ground color of the belly is gray, a little reddish. On each side on the dorsal margin of the gastrosteges there is a small light spot, a median black band extends from the first gastrosteges to the tip of the tail. On the anterior part there is a yellowish spot on each gastrostege in this black band and the thirty anterior spots cover this band nearly completely, but further back they become smaller and less distinct, disappearing on the tail.

Two of Cope's subspecies have twenty-one rows of scales, viz, $N$. $c$. compsolcema and $N$. c. compressicauda. The former is very different from this form, having "numerous dark crossbands, narrowed on the side; three gular yellow bands; a postocular band." The latter has "three rows of dorsal brown spots forming longitudinal bands on neck; one

\footnotetext{
${ }^{*}$ Proc. U. S. Nat. Mus., xiv, 1891, p. 666 (1892).

+ Since presented to the U. S. National Museum and catalogued as No. 21388.

$\ddagger$ Proc. U. S. Nat. Mus., XIv, 1891, p. 669 (1892).
} 
row of gular spots; no postocular bands." This one resembles somewhat the specimen from Key West, which is an intermediate form, but is darker than either.

\section{NATRIX FASCIATA (L in $\mathrm{n}$ æu s).}

This snake is very variable in several respects. The typical specimens of Natrix fasciata have the back with dark, nearly black, crossbands, or broad transverse spots on a lighter ground, usually brown or reddish brown; the black transverse spots are mostly bordered (at least on the sides) with narrow, yellowish stripes; the belly in different ways spotted or crossbanded with black. This is the commonest form in south Florida. Next to this type comes another, in which the ground color is more grayish brown or dull-brown, with narrow transverse (yellowish) lighter bands, which are surrounded or margined with broader blackish borders. Sometimes these bands are less distinct. Of this form I obtained several specimens from Orange and Osceola counties. A single specimen from Lake John, Orange County, had the back uniform brown (about chestnut color), but when the old skin was removed it was seen that only the back was marbled with black, which did not extend toward the sides, there being on the flanks a single row of large red spots. Belly spotted with red, denser on the posterior part and the underside of the tail. Only a small black spot on each side indicates the postocular band.

Another variety, still more distinct, is the one I found in February, 1893, at St. John's River, not far from Lake Jessup; if more specimens of the same kind should be found it may be regarded as a subspecies, for which I would propose the name Natrix fasciata atra. It may be described as follows: Head rather large and broad; body stout, with very strongly keeled scales in 23 longitudinal rows. Preocular, one; postoculars, two. Supra-labials, on one side, eight; on the other, nine. Above, uniform black; only a few scales on the posterior portion, with yellow centers; underneath, yellowish white, with the anterior part of each gastrostege black, thus forming narrow crossbands. The habitus is so different from Natrix fasciata that it struck me at once, and when first seen it reminded me strongly of a moceasin. It did not attempt to escape, but coiled up ready to strike. I was not quite sure about its non-poisonous nature until I had caught it and opened the mouth. It was $78 \mathrm{~cm}$. long, of which the tail measured $22 \mathrm{~cm}$.

The various forms of Natrix fasciata are often called "water moccasins" and regarded as poisonous and dangerous snakes. Although they are harmless they are "unpleasant and ill-tempered," as Jordan says.* In some lowland swamps in south Florida they are extremely abundant. At Arcadia, De Soto County, for instance, I once saw half a dozen in less than a minute. They used to stay at the borders of

* Jordan, D. S., Manual of the Vertebrate Animals of the Northern United States. 5 ed., Chicago, 1888. p. 194. 
ditches and ponds or lie, resting, on floating boards, stumps, etc. At the approach of a person they dive and hide in the mud, but if they can not escape they bite wildly.

\section{NATRIX CYCLOPION (Duméril \& Bibron).*}

I obtained only one specimen of this rare snake, and that one is small, though it is easily recognized. Scales in 29 rows; two small subocular plates, or scales, on each side. Temporals, 1-2, and a third one behind these, not touching the anterior one. The temporals indicate the difference from $N$. taxispilota, and the number of scale rows the difference from the $N$. fasciata group. The color is light grayish brown, with numerous narrow, dark erossbands, which are partly brokeu up into six series of spots. My specimen is from Orange County.

\section{NATRIX TAXISPILOTA (Holb rook).}

Of this big water snake I saw quite a number on the shores of Lake Apopka, Orange County. They may be seen resting on objects floating in the water, or on grass and branches overhanging the water, always diving when approached. I could not catch any alive, but had to sboot them in order to obtain specimens.

One large female had on the right side the normal number of oculars, viz, 1-2, but on the left side 1-3. Another had on both sides 2-3 oculars, and the same is the case with a smaller male specimen. When the oculars are 1-2 the eye rests on one of the labials, but when there are 3 postoculars the lowest one separates the eye from the labials. The number of oculars is consequently quite variable and seems to be of but little use as a specific character. The reduced size of the parietals, however, as well as the number of temporals, shows that my specimens belong to $N$.taxispilota. The male specimen has 29 rows of scales. The ground-color is mostly grayish brown, with alternating darker dorsal and lateral square spots which do not touch each other. Other specimens are darker, nearly black, and then the spots become less conspicuous.

\section{STORERIA DEKAYI ( Holb rook).}

At Kissimmee, Osceola County, near the shore of the Lake Tohopekaliga, I found a specimen of this snake. It was in February, and, although the day was warm and sunny, the snake was hidden under a piece of board. The upper part of the forehead, extending backwards over the greater part of the parietals, and the cheeks to the posterior margin of the eye, are of a dark brown color. The posterior part of the head is of a yellowish gray clay color, with the exception of two large, nearly triangular, black patches on the sides of the occiput. The lightcolored stripe formed by the interspace between those two patches extends forwards to the parietals, nicking into the brown color. The 
back of the body is of a grayish clay color, with two rows of small illdefined black spots, one on each side of the median line. These spots gradually become still less distinct backwards and disappear on the tail, which is more brown. On the sides some of the scales are darkedged, particularly on the anterior part of the body. The belly is pale gray, with a dirty yellowish tinge. The sides of the gastrosteges are finely mottled with very small black dots.* The total length was $245 \mathrm{~mm}$., the head and body $190 \mathrm{~mm}$., and the tail $55 \mathrm{~mm}$.

I wish to call attention to the fact that the number of scale rows of this specimen is 15 , the same as in the one recently described by Dr. O. P. Hay $\dagger$ as Storeria victa from Oklawaha River, Florida, some distance to the north of Kissimmee. In other respects my specimen shows no special agreement with Hay's description or disagreement with that of typical S. dekayi. With only these two specimens thus far obtained in Florida the status of S. victa must remain doubtful, as it will require more material to decide whether the difference in the scale formula is constant or not.

\section{STORERIA OCCIPITOMACULATA, (S to r e r).}

Mr. S. Robinson, of Orlando, gave me, last April, a small red snake which he had caught at Oklawaha River, 10 miles southeast from Ocala, Marion County. The color of the living snake was as follows: Back, uniform dark red or "cherry-red;" belly, salmon or rather miniumcolored; snout and anterior portion of head, brownish yellow; on the upper part of the neck a yellow half collar; tip of snout and chin, whitish; head underneath reddish, mottled with black; a narrow black mottled stripe on each side extends along the upper part of the gastrosteges, but becomes more and more faint posteriorly until it is no longer conspicuous $20 \mathrm{~mm}$. behind the head; a small light spot on the fifth upper labial; mouth, brown; total length, $190 \mathrm{~mm}$. In alcohol a faint light stripe extends from the yellow collar some distance backwards, but soon disappears. Although the color seems to be more brilliant than usual, I have no doubt it is a Storeria occipitomaculata, as the scutellation is the normal one of this species.

TAN'TILLA CORONATA, Baird and Girard.

In a rotten stump at Oakland I obtained a little Tantilla, and another one in the neighborhood of Apopka, Orange County. The last-mentioned is a typical Tantilla coronata in most respects, only the color is a little lighter than Baird \& Girard describe it, $\ddagger$ as it is light yellowish gray, with a faint brown tinge along the back; below, whitish; head, above dark brown with narrow yellowish collar. In this specimen the

* See Holbrook, J. E., North American Herpetology, 2 ed., Iv, pl. xiv.

† Science, xIx, April 8, 1892, p. 199.

$\ddagger$ BaIrd and Gira Rd, Catalogue of North American Reptiles, I, Serpents, p. 131. 
plates of the head are normal, except that the first pair of infralabials do not come in contact on the middle line, although very close together. The specimen from Oakland gave me at first much more trouble in classifying, as the prefrontals are completely fused with the preorbitals into one large plate on each side, extending down in front of the eye to the labials and separating the eye from the post-nasal. The color is the same as in the above-mentioned specimen. I take this to be only an individual variation.

\section{ELAPS FULVIUS (Linnæus).}

This is the only species of Elaps I have found in south Florida, where it is rather common. It is known under several names, as "coral snake," "American cobra," "garter snake," and "candy-stick." It is perhaps the most dangerous snake in Florida, because it is not so much dreaded as the big rattlesnake or moccasin, though being quite as poisonous. As the last-mentioned names show, it is regarded as a "pretty little snake." Few people know or believe that it is poisonous, it looks so harmless, and as a consequence they catch it and handle it rather roughly; the snake gets angry, bites, and a human life is endangered. I know personally of such a case. A Swede at Oakland, Orange County, found an Elaps, and because of its very beautiful color he caught it and tried to put it into a bottle of alcohol. The snake bit him, but the wound was not large, and as it did not swell he did not care much about it at first. After a while he was taken very sick, went to bed, asked for a physician, and drank whisky; but it was then too late. He died next morning, about 12 hours after the snake had bitten him. During the last hours he was unconscious, but before that he suffered most excruciating pains. I have heard of several other cases of boys dying from the effects of an Elaps bite.

In other cases people have been bitten by an Elaps fulvius without suffering from it in any way, but I suppose that in such cases the Elaps had not been able to inject any poison into the wound, as it has a rather small mouth. However that may be, I cannot agree with Cope* that the bite "of the smaller ones (meaning smaller species of Elaps) is innocuous to man and the larger animals." It is to be observed that the Elaps bites differently from the Crotalids and Viperids. The latter snake throws its head forward, in striking, and draws it back again immediately. The Elaps fulvius, I have seen and heard about, have acted in an entirely different manner. The poor Swede above mentioned had to pull the snake from the wound, and other specimens that I induced to bite into sticks kept the stick in the mouth for a good while. This habit probably signifies an intention to press as much poison as possible into the wound, which makes the snake the more dangerous. Elaps fulvius is, however, a good-natured snake, and it does

\footnotetext{
${ }^{*}$ Proc. U. S. Nat. Mus., xIv, 1891, p. 680 (1892).
} 
not bite unless it is very much provoked. If not handled too roughly an Elaps may be allowed to crawl on one's hands from one to the other. I have allowed it myself once, but I hardly think I would do it over again, and would not advise anybody else to try it.

I have found Elaps fulvius under logs and digging in the ground as well as crawling about on the surface, but I think it prefers dry land.

The largest specimen I have seen was from Oakland, Orange County, and measured exactly 1 meter from the tip of the nose to the anus, and the tail was $90 \mathrm{~mm}$. This big specimen had 14 black rings on the body and 3 on the tail. Other specimens have but 12 black rings on the body and 3 on the tail, but one of these has 4 on the tail. The yellow rings cover from one to two rows of scales.

SISTRURUS MILIARIUS ( $\mathrm{L}$ in $\mathrm{n}$ æu $\mathrm{s}$ ).

The ground rattlesnake is not rare in south Florida. Ihave obtained specimens from different places in Orange and Hillsboro counties. The specimens from the latter place, near the Gulf coast, are darker and have no reddish brown between the black dorsal spots. The latteral spots, too, are larger and more distinctly black. Even the rattle is darker and larger, and the tip of the tail is not yellowish as in the others. The ground rattlesnake likes dry ground.

CROTALUS ADAMANTEUS, Beauvo is.

In the interior of the country the diamond-backed rattlesnake is scarce, but not so along the coast and on some of the Florida keys. In the neighborhood of Ozona, in Hillsboro County, I heard of the killing of nine rattlesnakes within two weeks in October, 1892. It evidently prefers the neighborhood of the water, and is a good swimmer, not afraid to cross over from "key" to "key." If not too often disturbed this species is slow and does not rattle unless offended. I saw one in the latter part of October in the pine woods near Toronto, Orange County, coiled up under a palmetto bush. A dog following us went up and suiffed at him, with his nose hardly a foot from the snake. We called the dog back and a man ran forward with a whip and struck the snake several times. After the second blow the snake began to rattle and made himself ready to strike. This shows plainly the slow nature of the snake. In other cases they are more easily offended. Those kept in boxes and cages often begin to rattle as soon as they see anybody approaching. They are easy to keep alive and take food without trouble. I saw one that was kept in a small box and was fed with toads; it did so well there that it changed its skin twice in a summer. They are often kept in the shops of taxidermists and in "curiosity stores," where Northern tourists buy them, paying good prices. The skin is often used for ornaments or for the manufacture of pocketbooks and similar objects.

People are very seldom bitten by rattlesnakes in Florida. The rattling, the strong odor, and the slowness of the snake are protective. 
This snake is often caught by placing an empty barrel over the coils, after which a board is shoved under the suake and the whole thing turned over.

AGKISTRODON PISCIVORUS (Lacépède).

"Moccasin," "Watermoccasin," "Stump-tail moccasin," and "Cottonmouth moccasin" are the names by which this much-dreaded snake is known in south Florida. It is rather common where it has not been exterminated by man, and has been still more abundant around the lakes and in the swamps. It is a very ugly-looking animal, and very slow. It prefers to lie on the river banks, or on logs and stumps near the water. I once saw one on the St. John's River, at Lake Jessup, which had filled its lungs with air and basked in the sun, floating on the surface with the entire body out of the water. The young ones have brighter colors and are then sometimes mistaken for $A$. contortrix, the "Copperhead," but this snake is not found in Florida. I once caught a young moccasin which was being attacked by a butcher bird.

A very interesting fact which I have observed is that a moccasin, when it is angry and ready to bite, rattles with the tail like a rattlesnake. That other snakes have acquired this habit of scaring their enemies by making them believe that they are dangerous rattlesnakes is not so difficult to understand. But why does the moccasin rattle? That the rattling with the tail even by other suakes has something to do with the rattlesnake seems plain; for, why do not the non-American snakes rattle with the tail when excited? If the rattling only was something analogous to the playing with the tongue, why do not all snakes do it?

\section{General remarks.}

If we regard the Florida snakes observed by me, from a biographical point of view, under the heads of burrowing, climbing, crawling, and swimming species, the result may be tabulated as follows:

Burrowing species.

Cemophora coccinea.

Farancia abacura.

Osceola elapsoidea.

Stilosoma extenuatum.

Heterodon platyrhinos.

Tantilla coronata.

Elaps fulvius.

Total, 7 species.

\section{Climbing species.}

Opheodrys astivus.

(Bascanion constrictor).

(Callopeltis quadrivittatus).

Total, $1(+2)$ species.
Crawling species.

Lampropeltis getulus.

Diadophis punctatus.

Bascanion constrictor.

Bascanion flagellum.

Callopeltis guttatus.

Callopeltis quadrivittatus

Spilotes corais.

Pituophis melanoleucus.

Thamnophis sirtalis.

Thamnophis sackenii.

Storeria dekayi.

Storeria occipitomaculata.

Sistrurus miliarius.

Crotalus adamanteus.

Total, 14 species. 
Swimming species.

Contia pygaa.

(Farancia abacura).

Liodytes allenii.

Natrix compressicauda.
Swimming species-Continued.

Natrix fasciata.

Natrix cyclopion.

Natrix taxispilota.

Agkistrodon piscivorus.

Total, $7(+1)$ species.

It will be seen that there are as many burrowing species as there are water snakes, the light soil of Florida being very well adapted for subterranean life. Between the different categories there are, of course, no sharp limits.

The following species of snakes seem to be peculiar to Florida:

Contic pygaa, Cope.

Stilosoma extenuatum, Brown.

Callopeltis rosaceus (Cope).

Natrix usta, Cope.

Of the genera of snakes, only Stilosoma and Liodytes appear to be peculiar.

\section{BATRACHIA.}

\section{CAUDATA.}

\section{MANCULUS QUADRIDIGITATUS ( $\mathrm{H}$ ol b rook).}

I have found this animal under old $\operatorname{logs}$ at the border of a small lake at Clarcona and at Lake $\mathrm{John}$, and caught it in my dipnet in Fern Creek, near Orlando, Orange County. On land it is rather swiftrumning, and lives in localities similar to those which are frequented by Leiolopisma laterale. These two animals are also similar in color. Several of my specimens had well-developed cirri. One specimen in the U. S. National Museum (No. 21328).

\section{DESMOGNATHUS AURICULATA (Hol b rook).}

I have only found one specimen of this species under a $\log$ in a wet hammock near Lake Jessup, Orange County. It is found in Georgia, but I do not know that it has been reported from Florida before.

\section{DIEMYCTYLUS VIRIDESCENS, $R$ a f i n es q u e .}

In a small but deep pond, with clear water and steep slopes all around, I caught a number of larvæ which, according to Dr. Stejneger's opinion, belong to this species. I have not seen it at any other place in Florida except in this pond, situated between Oakland and Lake John, in Orange County, but here many specimens were seen.

\section{AMPHIUMA MEANS, Gar den.}

It is known under the name of "mud eel" or "mud puppy," and is not rare in Orange County, where I have caught specimens at Oviedo, Proc. N. M. $94-22$ 
Apopka, and Orlando. People digging in the "muck" find them frequently in such soil, and I have taken them with my net in ponds and small lakes.

\section{SIREN LACERTINA, Li in $n$ æ u s .}

A man living at Oakland, Orange County, told me that he once had taken two specimens of the "gray mud puppy" on hook and line in Lake Apopka. I did not see any myself.

\section{ECAUDATA.}

BUFO LENTIGINOSUS, S h a w .

This is the most common toad in south Florida. It is seen in great numbers about the houses and other places in the evening. In the daytime it hides under old $\operatorname{logs}$, boards, etc., at the shores of lakes and other moist places.

\section{BUFO QUERCICUS, Holb roo k.}

This is a very active little animal considering the fact that it is a toad. It is seen in all kinds of places and at all times of the day, even in the brightest sunshine, but especially after rain. I have seen it very abundant on the dry sandhills about Oakland, Orange County, as well as in the "flatwood" about Kissimmee, Osceola County, and in Hillsboro County. The specimens from the latter place are a little different, as the frontal ridges are less prominent, straight behind, and the color of the back is redder.

\section{ENGYSTOMA CAROLINENSE, Holbrook.}

I have found this peculiar little animal under old logs, dry palmleaves and such things, near lakes and in moist places in Orange County, for instance, in the pineland at Clarcona, and in the hammocks bordering Lake Jessup. It is not very common.

\section{ACRIS GRYLLUS (L e Conte).}

In south Florida, along the borders of ponds and swamps, this frog is abundant though not commonly seen. All my specimens show the triangular black spot on the head. The median dorsal stripe is always reddish brown, and I have never seen it green. The posterior femoral stripes are very conspicuous. The light stripe from the orbit to the axilla is constant, but the other blotches are not always light bordered.

HYLA SQUIRELLA, Latreille.

I take this to be the most common Hyla in south Florida. My specimens are from Hillsboro and Orange counties. 
HYLA FEMORALIS, Latreille.

I obtained several specimens of this species in Orange County. I think it is the Hyla of the pine woods.

RANA CATESBEIANA, Shaw.

Very abundant in south Florida in ditches, ponds, swamps, and other wet places. It seems to like sluggish water and muddy bottom. My largest specimen was eaught at Lake Eola, Orange County. It was when alive only $10 \mathrm{~mm}$. smaller than the largest one in the $\mathrm{U}$. S. National Museum, recorded by Cope.*

\section{RANA PIPIENS, Schreber.}

This is the most common frog in south Florida and is found everywhere in wet places. Some specimens come nearer to R. p. sphenocephala, others to typical $R$. pipiens, and it is difficult to draw any definite line. It is called "Spring frog." It has a great faculty of changing color between grass-green and brown. When it has turned green it is very beautiful.

\section{RANA CLAMATA, Daudin.}

Common near some ponds and small lakes in Orange County, but I could not catch any as they used to jump into the water with a cry long before I reached them.

\section{RANA ESOPUS, Cope.}

Of this species I have collected one specimen at Ozona, Hillsboro County. It was caught with hook and line in a small pond, and was called "snake frog" by the population there. I have seen it but rarely, and must conclude that it is either scarce or else that its habits are such as to prevent it from being observed. It agrees with Cope's description in every essential, but the throat is spotted with numerous elliptical or rounded spots of dark brown color. Two smaller specimens of the same kind were caught in Orange County, at Lake Jessup and Clarcona. 


\section{$2 \mathrm{BHL}$ Biodiversity Heritage Library}

1894. "Notes on reptiles and batrachians collected in Florida in 1892 and 1893." Proceedings of the United States National Museum 17(1003), 317-339. https://doi.org/10.5479/si.00963801.17-1003.317.

View This Item Online: https://www.biodiversitylibrary.org/item/53454

DOI: https://doi.org/10.5479/si.00963801.17-1003.317

Permalink: https://www.biodiversitylibrary.org/partpdf/52140

\section{Holding Institution}

Smithsonian Libraries

\section{Sponsored by}

Smithsonian

\section{Copyright \& Reuse}

Copyright Status: Public domain. The BHL considers that this work is no longer under copyright protection.

This document was created from content at the Biodiversity Heritage Library, the world's largest open access digital library for biodiversity literature and archives. Visit BHL at https://www.biodiversitylibrary.org. 